\section{Цепочки добавленной стоимости как инструмент развития угольной отрасли}

С.М. НИКИТЕНКо, Федеральный исследовательский центр

угля и углехимии СО РАН, Российский экономический университет имени Г.В. Плеханова (Кемеровский институт).

E-mail: nsm.nis@mail.ru

Е.В. ГООСЕН, Федеральный исследовательский центр угля и углехимии

СО РАН, Кемеровский государственный университет, Кемерово

В статье рассматриваются проблемы и перспективы развития угольной отрасли, анализируются пути диверсификации экономики угледобывающего региона на базе реализации теории цепочек добавленной стоимости. Обоснована возможность использования в практике угледобывающих и перерабатывающих компаний инновационных технологий добычи, транспортировки, обогащения и глубокой переработки угля как альтернативного пути интенсификации освоения месторождений и формирования новых технологических цепочек на основе сотрудничества с предприятиями машиностроительной отрасли.

Ключевые слова: цепочки добавленной стоимости, рациональное недропользование, государственно-частное партнёрство, топливно-энергетический комплекс, территориальное развитие, инновации

Проблемам диверсификации ресурсных экономик, в том числе с помощью кластерных проектов, государственно-частного партнерства и пр., в последние годы уделяется много внимания. Однако, как показывает опыт, большинство этих инициатив не привело к позитивным результатам.

Целью предлагаемой статьи является объяснение на основе теории цепочек добавленной стоимости проблем и перспектив развития угольной отрасли и поиск путей диверсификации экономики Кемеровской области.

\section{Проблемы развития угольной отрасли в России и Кузбассе}

По данным ВP Statistical Review of World Energy (июнь 2016 г.), Россия к концу 2015 г. занимала второе место в мире

" Статья подготовлена при финансовой поддержке Российского научного фонда (Соглашение № 16-18-10182, проект «Формирование организационно-экономических механизмов комплексного освоения недр в регионах ресурсного типа на основе партнерства науки, власти и бизнеса»). по доказанным запасам природного газа, шестое - нефти и седьмое - угля [1]. На долю России приходилось 17\% мировых запасов газа, по 6\% - нефти и угля [2]. Важная часть топливноэнергетического комплекса - угольная отрасль - имеет большое значение для социально-экономического развития страны в целом и особенно ее угольных регионов.

Угольная отрасль России, как и газовая, крайне зависима от внешней конъюнктуры: дальнейший рост ограничивают емкость внешнего рынка и стоимость добычи и транспортировки, а не запасы угля или добывающие мощности. Прирост добычи угля в России в 2006-2016 гг., составлявший в среднем 3\% в год (с 309,4 до 385,4 млн т), обеспечивался в основном за счет увеличения доли экспорта в общем объёме отгрузки угля. Развитию отечественной отрасли препятствует превышение предложения угля над спросом, которое вызвало долговременное снижение цен на мировых угольных рынках, привело к перераспределению мировых потоков угля и обострению конкуренции на традиционных рынках сбыта [3].

Процессы на мировом угольном рынке, в частности климатическая политика многих стран (особенно ЕС и Китая), создают высочайшую неопределенность для этой отрасли в России. Стагнация внутреннего спроса на твердое топливо на фоне невысоких темпов роста экономики и сохранения относительно низких цен на газ делают экспорт основным драйвером развития угольной промышленности.

Доля поставок на экспорт увеличилась с 29\% в 2006 г. до 43\% в 2016 г. При этом за 2014-2016 гг. объемы экспорта стали сокращаться за счет снижения спроса на зарубежных рынках (рис. 1). На сегодняшний день добыча российского угля поддерживается, в основном, за счет спроса на внутреннем рынке. При этом в условиях общего падения цен на внешнем и внутреннем рынках энергоносителей можно ожидать обострения конкуренции между производителями угля и газа и сокращения внутреннего спроса на уголь [3].

Данные статистики убедительно показывают, что отрасль исчерпала возможности экстенсивного роста и нуждается в серьезной перестройке. 


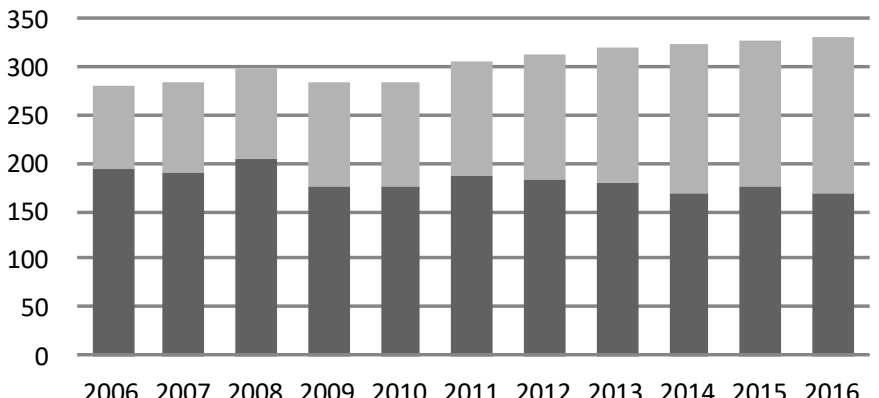

- Поставка угля на внутренний рынок Отгрузка угля на экспорт

Рис. 1. Динамика структуры поставок российского угля в России в 2006-2016 гг., млн т [4]

В наиболее тяжелом положении находится Кузбасс - основной угольный бассейн России. В регионе добывается $61 \%$ угля страны, на него приходится 76\% экспорта. В 2015 г. в Кемеровской области было добыто 215,6 млн т угля (+1,9\% к 2014 г.). Ресурсная ориентация до 2009 г. обеспечивала Кемеровской области достаточно высокие темпы роста и уровень доходов населения, однако ограничивала возможности развития других отраслей, усиливала процессы дезинтеграции. За 2010-2015 гг. объём государственного долга региона вырос в три раза и составил 62,5 млрд руб. - почти $80 \%$ от доходов областного бюджета. По оценке журнала «Профиль», Кемеровская область по общей сумме долга занимает восьмое место среди российских регионов [5].

Сложившуюся в регионе ситуацию можно объяснить негативными мировыми и общероссийскими тенденциями (падение в разы мировых цен на уголь и металлы, спад экономики, санкции, снижение реальных доходов населения, а также инвестиционной и предпринимательской активности). Но, думается, фундаментальные причины связаны с особенностью участия России в глобальных цепочках добавленной стоимости (ЦДС) и спецификой ЦДС, формируемых крупнейшими российскими вертикально интегрированными компаниями на внутреннем рынке.

\section{Участие России в мировых ЦДС}

Теория цепочек добавленной стоимости. Эта теория, возникшая на рубеже 1960-1970-х гг., пыталась ответить на вопрос: почему одним странам удалось обеспечить высокие темпы роста и развития за счет инноваций и участия в глобальном разделении труда, а другие отстали? Для этого были проанализированы степень и характер вовлечения стран и регионов в процесс создания стоимости по всей технологической цепочке, от процесса добычи ресурсов до реализации готового продукта (услуги) на рынке.

Зарубежные и российские исследования демонстрируют эффекты ЦДС на локальном уровне (регионы, отрасли и кластеры) и механизмы влияния крупных глобальных вертикально интегрированных компаний на выбор страной (регионом) специализации, а также потенциальные возможности и риски встраивания в современные рынки и альтернативные сценарии смены этой специализации, что крайне актуально для стран и регионов с сырьевой направленностью развития $[6,7]$.

Автором теории ЦДС считается М. Портер, который описал вертикальную цепочку добавленной стоимости на уровне отдельной компании [8]. Т. Сторджен (его определение взято за основу в настоящей статье) в общем виде описал ЦДС как механизм начисления стоимости в процессе создания конечного продукта, который включает в себя различные стадии разработки, производства, в том числе дизайн, и сбыта готовой продукции [9]. В докладе ОЭСР (2013 г.) ЦДС определены как «весь процесс производства товаров, от сырья до конечного продукта» [10].

Внутри цепочки можно выделить два типа связей - восходящие и нисходящие [10].

Восходящие связи чаще всего формируются в рамках экспортно-ориентированной модели вокруг отраслей с процессным производством (химическая, нефте-, угледобывающая и металлургическая). Страна (регион) добывает и отправляет на экспорт сырьевые товары и услуги с невысокой добавленной стоимостью, которые в дальнейшем возвращаются в виде готовой продукции с высокой добавленной стоимостью. Для восходящих цепочек добавленной стоимости характерна низкая локализация в регионе перерабатывающих, смежных и обеспечивающих производств. Поэтому страны, в ЦДС которых преобладают восходящие связи,- это экспортеры сырья, производители комплектующих 
и компонентов для создания сложной продукции с высокой добавленной стоимостью [10].

Нисходящие цепочки добавленной стоимости появляются вокруг производства и экспорта высокотехнологичных инновационных конечных товаров и услуг, при этом сырьевые товары и услуги, наоборот, экспортируются. Центрами их формирования являются крупные вузы, НИИ, опытно-конструкторские и инжиниринговые центры. В противоположность восходящим создание нисходящих цепочек добавленной стоимости сопровождается высокой локализацией в стране (регионе) перерабатывающих, смежных и обеспечивающих производств [10].

Данные рисунка 2 показывают, что в большинстве случаев страны, в которых преобладают нисходящие связи, развиваются более успешно и более восприимчивы к инновациям.

$\%$

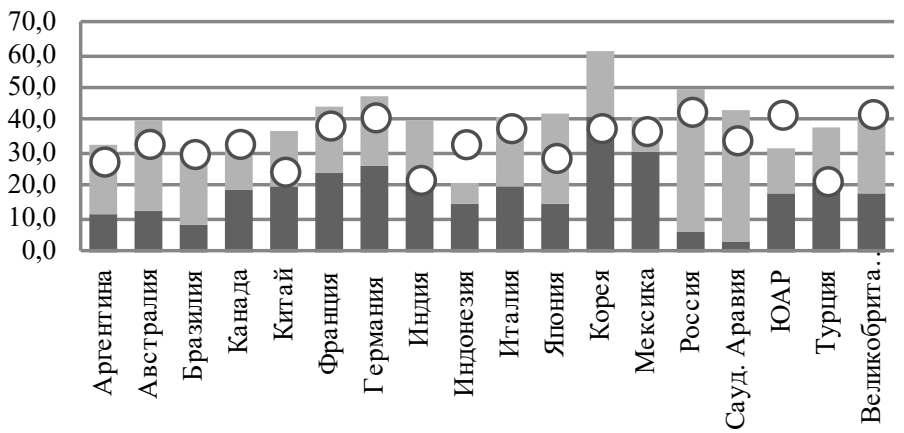

口 Экспорт промежуточных товаров, использовавшихся для экспорта в третьи страны в 2009 г. (нисходящие связи)

Импортные ресурсы, использовавшиеся в экспорте в 2009 г. (восходящие связи)

о Общее участие в ЦДС в 1995 г.

Рис. 2. Участие отдельных стран в ЦдС в 1995 г. и 2009 г. [11], \%

Влияние цепочек добавленной стоимости на страны и регионы во многом зависит от типов ЦДС, отражающих характер управления и связей внутри цепочки - от поставщиков к потребителям, а также асимметрию рыночной власти [11].
В рыночных цепочках добавленной стоимости игроки обладают одинаковой рыночной властью, система управления ЦДС децентрализована, процесс взаимодействия идет на горизонтальном уровне на основе рыночного взаимодействия. Для рыночных ЦДС характерна изменчивость, связанная с легкостью смены партнера.

Рыночной ЦДС противостоят иерархически организованные вертикальные цепочки. Они чаще всего представлены одной вертикально интегрированной компанией, в которой процесс управления максимально централизован, и никто из «внешних участников» не может войти в цепочку. Фирма осуществляет жесткий мониторинг и контроль всецело зависящих от нее мелких поставщиков, контролирует поток ресурсов и производимой продукции, в результате чего формируется своеобразный закрытый анклав. В рамках анклава концентрируются лучшие ресурсы. Значительный масштаб производства и вертикальные связи позволяют существенно экономить на производственных и трансакционных издержках, контролировать цены на конечную продукцию. Ярким примером таких ЦДС являются крупные вертикально интегрированные компании, занятые добычей и переработкой сырья.

Такие компании, формирующие ЦДС, могут значительно ускорить процессы развития регионов и отдельных секторов экономики, однако их «закрытый» характер не позволяет им развиваться сбалансированно. Вертикальные ЦДС не генерируют горизонтальные связи, ограничивают развитие внутреннего рынка, формируют и закрепляют моноотраслевую специализацию стран и регионов базирования. Особенно сильно негативное влияние иерархической ЦДС проявляется, если вертикально интегрированная компания работает в сырьевом секторе, а в цепочке, формируемой в стране и регионе, преобладают восходящие связи и стадии добычи и первичной переработки сырья. Это объясняется тем, что наибольший объем добавленной стоимости приносят стадии, наиболее отдаленные от процесса производства, - научные исследования и разработки и послепродажное обслуживание. Поэтому в вертикальных ЦДС задействованы страны и регионы, на долю которых приходятся стадии добычи и первичной переработки ресурсов наименьшую долю добавленной стоимости, создаваемой в ЦДС [11]. 
Вовлеченность России и Кузбасса в глобальные ЦДС. По данным ОЭСР, в 2013 г. Россия имела индекс участия в глобальных цепочках добавленной стоимости на уровне 51,8\% и занимала 25-е место из 57 стран [11]. При этом страна в наибольшей степени участвовала в восходящих ЦДС (индекс-86\%), поставляя на экспорт сырье и материалы и приобретая готовую продукцию [12].

Большая часть ЦДС, в которых участвует Россия, имеет ярко выраженную иерархическую структуру и контролируется отечественными вертикально интегрированными компаниями. Восходящий тип связи преобладает в горнодобывающей, химической промышленности и металлургии, оптовой и розничной торговле, транспортном и металлургическом секторах. При этом, по оценкам ОЭСР, индекс участия России в нисходящих глобальных цепочках в 2015 г. составил всего 13,7\%, что является шестым показателем с конца. По уровню вовлечения в нисходящие ЦДС Россия опережает только Индонезию, Бразилию, Колумбию, Бруней и Саудовскую Аравию. Важно, что большая часть этих ЦДС формируются с привлечением крупных зарубежных ТНК, выступающих в качестве ведущих подрядчиков и посредников и формирующих ЦДС вертикального типа [12].

Такая специализация ведет к тому, что внутри страны не создается высокая доля добавленной стоимости, а экспортируемые отечественными вертикально интегрированными компаниями природные ресурсы возвращаются в страну в виде готовых зарубежных товаров со значительной наценкой.

При этом преобладание вертикальных ЦДС блокирует развитие высокотехнологичных отраслей, препятствует развитию внутреннего рынка, закрепляет ресурсную специализацию регионов.

В угольной отрасли России, где доминируют крупные вертикально интегрированные угледобывающие и металлургические холдинги, эта ситуация проявляется наиболее ярко. В таблице 1 приведены данные о первой десятке компаний, которые обеспечивают $58 \%$ добычи угля в стране.

Важно, что все эти крупные вертикально интегрированные компании характеризуются ярко выраженными восходящими
ЦДС как на внешнем, так и на внутреннем рынках. Многие из них имеют подразделения на территории Кузбасса (табл. 2).

Таблица 1. Крупнейшие российские угледобывающие компании по итогам 2014-2015 гг. [13]

\begin{tabular}{|c|c|c|c|c|}
\hline \multirow[t]{2}{*}{ № } & \multirow[t]{2}{*}{ Компания } & \multicolumn{2}{|c|}{$\begin{array}{c}\text { Объем добычи угля, } \\
\text { млн т }\end{array}$} & \multirow{2}{*}{$\begin{array}{c}\text { Доля в общей } \\
\text { добыче угля } \\
\text { в России, \% }\end{array}$} \\
\hline & & 2014 & 2015 & \\
\hline 1 & ОАО «СУЭК» & 98,9 & 97,8 & 20 \\
\hline 2 & ОАО УК «Кузбассразрезуголь» & 44,5 & 44,5 & 9 \\
\hline 3 & АО УК «СДС уголь» & 29,7 & 30,0 & 6 \\
\hline 4 & ОАО «Мечел-МайнинГ» & 23,2 & 23,2 & 5 \\
\hline 5 & OAO «EBPA3» & 21,8 & 20,6 & 4 \\
\hline 6 & ОАО «Русский уголь» & 13,6 & 14,4 & 3 \\
\hline 7 & ОАО «Воркута уголь» & 11,4 & 13,2 & 3 \\
\hline 8 & 000 «Компания “Востсибуголь” & 12,1 & 13,0 & 3 \\
\hline 9 & ООО Холдинг «Сибуглемет» & 10,9 & 10,8 & 2 \\
\hline 10 & $\begin{array}{l}\text { ОАО «Кузбасская топливная ком- } \\
\text { пания» }\end{array}$ & 10,6 & 11,0 & 2 \\
\hline
\end{tabular}

Таблица 2. Особенности ЦДС, контролируемых крупнейшими угледобывающими предприятиями России

\begin{tabular}{|c|c|c|c|}
\hline № & Компания & $\begin{array}{c}\text { Структура рынка и место } \\
\text { в глобальной и национальной } \\
\text { цдС }\end{array}$ & Структура ЦдС предприятия \\
\hline 1 & ОАО «СУЭК» & $\begin{array}{l}\text { Крупнейший поставщик угля } \\
\text { для энергетических компаний } \\
\text { на внутреннем и внешних рынках } \\
\text { (почти 45\% от общего объема } \\
\text { добытого угля) }\end{array}$ & $\begin{array}{l}\text { Научные исследования и раз- } \\
\text { работки, добыча, обогащение } \\
\text { и перевозка угля, логистика, сбыт }\end{array}$ \\
\hline 2 & $\begin{array}{l}\text { ОАО УК «Кузбассраз- } \\
\text { резуголь» }\end{array}$ & $\begin{array}{l}\text { Крупнейший экспортер: } 25 \% \\
\text { кузбасского и почти } 20 \% \text { россий- } \\
\text { ского угольного экспорта }\end{array}$ & $\begin{array}{l}\text { Добыча, обогащение и перевозка } \\
\text { угля, логистика, сбыт }\end{array}$ \\
\hline 3 & АО УК «СДС уголь» & $\begin{array}{l}\text { Входит в тройку крупнейших } \\
\text { экспортеров угля в России (87\% } \\
\text { добываемого угля экспортируется) }\end{array}$ & $\begin{array}{l}\text { Добыча, обогащение и перевозка } \\
\text { угля }\end{array}$ \\
\hline 4 & $\begin{array}{l}\text { ОАО «Мечел-Май- } \\
\text { нинг» }\end{array}$ & $\begin{array}{l}\text { Дивизион металлургического } \\
\text { холдинга, ориентированного } \\
\text { на экспорт }\end{array}$ & $\begin{array}{l}\text { Добыча, обогащение и перевозка } \\
\text { угля в структуре металлургическо- } \\
\text { го, энергетического производства, } \\
\text { организация сбыта }\end{array}$ \\
\hline 5 & OAO «EBPA3» & $\begin{array}{l}\text { Дивизион металлургического } \\
\text { холдинга, ориентированного } \\
\text { на экспорт }\end{array}$ & $\begin{array}{l}\text { Добыча, обогащение и перевозка } \\
\text { угля, организация сбыта }\end{array}$ \\
\hline 6 & ОАО «Русский уголь» & $\begin{array}{l}\text { Большая часть угля поставляется } \\
\text { на внутренний рынок (уголь для } \\
\text { электростанций и ЖКХ) }\end{array}$ & Добыча и обогащение угля \\
\hline
\end{tabular}




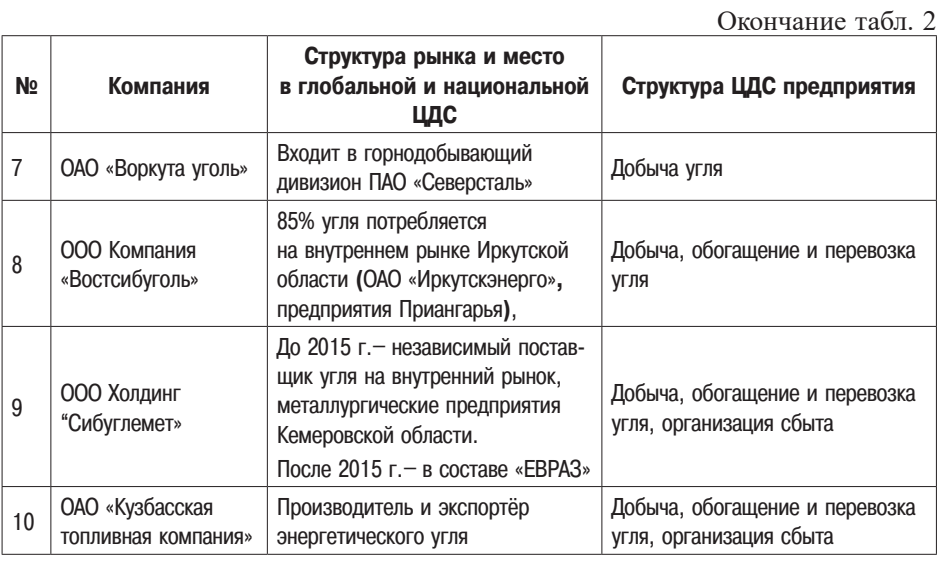

Источник: официальные сайты компаний.

Экономика Кемеровской области и, соответственно, создаваемые в регионе цепочки добавленной стоимости сформированы на основе добычи и обогащения угля. Эскпортно-ориентированная модель развития привела к тому, что в регионе сосредоточены в основном первые производственные стадии с минимальным числом производственных узлов (центров), которым свойственны такие черты, как капиталоемкость, низкий спрос на высокопроизводительную рабочую силу, научные исследования и разработки, незаинтересованность в развитии смежных и обеспечивающих производств. Именно этим объясняются невосприимчивость региона к инновациям, устойчивость его моноотраслевой структуры, сложности диверсификации экономики.

\section{Перспективы Цдс в Кузбассе: инновационные технологии добычи и глубокой переработки}

По мнению авторов, в угольной промышленности Кемеровской области разумно развивать и восходящие, и нисходящие ЦДС, которые должны дополнять друг друга. В результате глубокой переработки угля и техногенных отходов предприятий горнодобывающей отрасли можно получать до 130 видов химических продуктов и более 5 тыс. видов продуктов смежных отраслей. Благодаря глубокой переработке на основе угля можно получать синтез-газ, аммиак (азотные удобрения), кокс (сталь), каменноугольную смолу. Из каменноугольной смолы можно производить толуол, тротил, нафталин, красители, бензол, фенол. Из бензола - анилин и красители, из фенола - пластмассы и красители.

Известные в мире технологии позволяют получать из угля свыше пяти тысяч видов разнообразной продукции с высокой добавленной стоимостью. В настоящий момент промышленное применение в мире имеют четыре «ветви» переработки углей, образующие восходящие ЦДС.

1. Пиролиз (коксование) углей - получение кокса, полукокса, каменноугольных пеков, гуминовых кислот, нафталина, антрацена, фенантрена, бензола, каменноугольных масел, аммиака, фенола, крезола, пиридиновых оснований, коксового газа. Методом пиролиза получают около 680 млн т металлургического кокса и около 25 млн т каменноугольной смолы, только 50\% которой подвергается дальнейшей перегонке с целью получения товарной продукции. Другое направление угольной химии, основанной на металлургическом коксе, - цепочка «уголь - карбид кальция - ацетилен - поливинилхлорид», которая относится к «традиционной» углехимии и широко применяется в Китае.

2. Газификация углей - получение и очистка синтез-газа и его деривативов. Технология открывает новые возможности в разработке угольных пластов со сложными горно-геологическими условиями залегания, совмещает добычу, обогащение и переработку угля, обеспечивая при этом не только удлинение ЦДС, но и локализацию производства конечного продукта (горючего газа) непосредственно на месте добычи угольного пласта. Горючий газ может быть использован в качестве котельного топлива либо энергетического сырья для газотурбинных установок при производстве электроэнергии. Одно из достоинств такого метода глубокой переработки угля - его экологичность. Он практически не нарушает земную поверхность, а получаемый газ является более экологически чистым топливом, чем уголь [14].

Технологическое лидерство в области газификации за ведущими инжиниринговыми компаниями мира - General Electric, Shell, Lurgi, однако ускоренное развитие внутреннего рынка привело к возникновению собственных промышленных технологий в Китае (ECUST, MCSG, SEDIN), которые в среднесрочной перспективе могут оказать значительное влияние на конкуренцию в сегменте промышленных газификаторов. 
Федеральным исследовательским центром угля и углехимии СО РАН технологически и экономически обоснован инвестиционный проект, предполагающий строительство в Кузбассе шести крупных промышленных предприятий подземной газификации угля с производительностью до 4,0 млрд м ${ }^{3}$ горючего газа в год. Они могли бы осуществлять газификацию угольных пластов по новой современной технологии [14].

3. Непрямая гидрогенизация углей - получение жидких продуктов (бензина, дизельного топлива, смазочных масел, парафинов, фенолов) из смол газификации или пиролиза углей. В Институте горючих ископаемых РАН была создана экономически высокоэффективная технология, которая отличается от промышленной технологии Германии 1930-1940-х годов и соответствующих разработок, выполненных в США, Японии, Германии, Великобритании и других странах в последнее время, возможностью получения моторных топлив из угля по конкурентоспособным ценам в сравнении с производством их из нефтяного сырья. Эта технология включает ряд процессов, которые были усовершенствованы с использованием новейших достижений отечественной и зарубежной науки и практики последних лет [14]. Технология была отработана на опытной установке СТ-5 производительностью до 5 т угля в сутки. Строительство промышленной установки СТ-75 было начато на Березовском разрезе в г. Шарыпово, однако производство не было запущено из-за наступления периода перестройки. В настоящее время работы в этом направлении в стране практически не ведутся.

4. Прямая гидрогенизация углей - под давлением с получением моторного топлива и сырья для органического синтеза. Себестоимость полученных таким способом углеводородов выше, чем при их производстве из нефти.

Один из базовых продуктов химической промышленности во всём мире - метанол, который, в свою очередь, является исходным сырьём для производства формальдегидов (с последующим выпуском синтетических смол), для изготовления уксусной кислоты, диметилового и метил-трет-бутилового эфиров, олефинов и пр. В настоящее время мировой рынок испытывает дефицит метанола, поэтому технологическую цепочку «синтетический газ - метанол» можно рассматривать как важнейшую компоненту для развития углехимической отрасли в Кузбассе. А возможно- сти расширения технологической цепочки продуктов пиролиза (коксохимии) будут зависеть от объемов и доступности побочных продуктов коксования угля, а также от конкурентоспособности коксующегося угля как сырья для производства ацетилена, бензола и ароматических соединений по критериям объемов сырья, качества и цены [15].

Имеющиеся экономические расчёты подтверждают возможность обеспечить приемлемую себестоимость продуктов глубокой переработки углей и их конкурентные позиции на соответствующих рынках. В 2017 г. в Кузбассе пущена первая очередь завода по производству угольных сорбентов. Мощность пока небольшая - 60 т сорбентов в год, но уже к началу 2018 г. планируется нарастить выпуск до 125 т, а в перспективе - до 3 тыс. т.

Из-за санкций, введенных в отношении России Европейским союзом и США, приостановлена реализация в Кузбассе крупного проекта глубокой переработки угля, ориентированного на получение из него дизтоплива, битума и синтез-газа. Проект предполагает монтаж 10 установок глубокой переработки угля годовой мощностью 350 тыс. т каждая [5].

Тем не менее авторы статьи разделяют точку зрения экспертов (Ю.А. Фридман, Г.Н. Речко, Е. Ю. Логинова), которые считают, что создание полномасштабных углехимических производств в Кемеровской области либо массовое включение кузбасского угля в производственную цепочку углехимических предприятий за пределами региона - вопрос долгосрочной перспективы. Недостаточный уровень развития российского и глобального рынков современной наукоемкой углехимической продукции, безусловно, препятствует активному участию отечественного угольного бизнеса в подобных капиталоемких проектах [5]. Выходом из сложившейся ситуации могут стать различные формы сотрудничества бизнеса, науки и государства, позволяющие «расшить узкие места» и заполнить разрывы в технологических цепочках.

Перспективы новых технологий обогащения. Одним из направлений развития восходящих цепочек может стать рост объемов обогащения. В настоящее время в Кузбассе обогащается около 73\% добываемого угля (по России - чуть более 50\%), а к 2022 г. планируется эту цифру довести до 80\%. С этой целью в Новокузнецком районе ведётся строительство крупнейшего за последние годы комплекса по добыче и переработке угля, в ко- 
торый войдут новая шахта (1,5 тыс. рабочих мест) и современная обогатительная (250 рабочих мест). В целом по России к 2030 г. планируется увеличить долю обогащенного угля в 1,6 раза, доведя его объемы до 345 млн т. С этой целью планируется полностью обновить все производственные мощности обогатительных фабрик, введенных в XX веке [5].

Большую роль в повышении рентабельности «обогатительной цепочки» может сыграть совершенствование технологий обогащения и переработки угля, благодаря которым повышаются его потребительские свойства (энергетическая ценность, минимальная зольность), а также значительно снижаются затраты на транспортировку, что может способствовать развитию и нисходящих цепочек.

Использование современных обогатительных технологий, в основе которых лежит разделение угля в водной среде или тяжелой суспензии («мокрое» обогащение), сопряжено для предприятий с серьезными затратами. Для них необходимо создавать большое водооборотное хозяйство: очищать оборотную воду, подогревать ее, содержать водоотстойники. Большое количество жидких отходов приводит к образованию настоящих озер, а некоторые из шламонакопителей уже сопоставимы по площади с небольшими городами. Кроме того, эти искусственные водоемы постепенно смыкаются с реками, что создает опасность заражения окружающей среды. Особенно следует выделить проблемы обезвоживания и сушки угля, получаемого при «мокром» обогащении, отопления больших объемов помещений.

Альтернативные «сухие» методы обогащения угля, широкое применявшиеся в 1960-е гг., сейчас не используются из-за низкой эффективности устаревших технологий. Строительство же фабрик на основе «мокрого» обогащения чрезвычайно затратно. Получается замкнутый круг. Продавать необогащенный уголь сложно и невыгодно из-за его высокой зольности и низких цен. А строительство «мокрых» обогатительных фабрик (особенно на энергетических углях) слишком дорого, при этом рыночная цена обогащенного угля не покрывает высокие затраты. Выход один: использовать для обогащения угля такие технологии, которые позволят улучшить качества угля и одновременно снизить затраты.
Разработанная в Кузбассе уникальная технология «сухого» пневмовакуумного способа обогащения угля одновременно решает две проблемы - цены и качества. Строительство и эксплуатация новых фабрик обходятся гораздо дешевле традиционных, поэтому получаемый концентрат имеет низкую себестоимость при максимально высоком качестве. Финишное обогащение позволяет производить разделение компонентов с эффективностью не менее $96 \%$.

Технология реализована в виде мобильной установки пневмовакуумной сепарации сыпучих материалов (УПВС-01-09) открытого типа и защищена патентами на изобретение в России, США, Австралии, ЮАР, Украине, Казахстане, Турции. Установки уже используются на угледобывающих предприятиях Кузбасса (000 «Шахта 12», ЗАО «Салек», разрез «Майский» ОАО СУЭК-Кузбасс, ООО «Разрез Южный», ООО «Промугольсервис», 000 «Разрез им. В.И. Черемнова»). Уникальность технологии ещё и в том, что она позволяет «переобогатить» отходы (шламы) от «мокрых» фабрик в соответствии с самыми высокими международными требованиями. Низкозольные концентраты, получаемые пневмовакуумным способом, пользуются устойчивым спросом на внутреннем и внешнем рынках. Это открывает возможности для создания нисходящих ЦДС за счет экспорта технологий. Первая установка на основе российских разработок «сухого обогащения» смонтирована в Австралии, ведутся переговоры с деловыми кругами Польши, Турции, Индии и других стран.

Важным элементом таких нисходящих ЦДС являются инжиниринговые центры. Они специализируются на продаже и внедрении новых технологий обогащения минерального сырья и могут стать значимым фактором реализации инновационной модели угольного бизнеса и открыть возможности для формирования рынка угольной продукции в России и за рубежом, что позволит Кузбассу построить жизнеспособную модель своего будущего развития и занять стратегическую рыночную нишу. Такой подход открывает возможности для следующего шага создания в Кемеровской области и других угледобывающих регионах центров глубокой переработки угля с получением широкой номенклатуры востребованной на рынке продукции.

Опыт США, Великобритании, Норвегии показывает, что модернизация и переход добывающих отраслей на интенсивный путь развития невозможны без тесного сотрудничества с университетами и машиностроительными компаниями, занятыми разработкой технологий и производством оборудования для шахт и разрезов. Именно такой подход формирует нисходящие ЦДС, превращая новые знания в технологические инвестиции, и создает основу интенсивного развития угольной отрасли [7]. 
К сожалению, сегодня в угольной отрасли и Кемеровской области в большинстве случаев применяются такие технологии добычи угля, которые предопределяют экстенсивный путь освоения месторождений и формируют укороченные восходящие ЦДС. На-гора выдается лишь тот уголь, добывать который рентабельно при существующем оборудовании, а «нерентабельный» просто оставляют «на потом». В результате Кузбасс «теряет» безвозвратно в год 500-600 млн т запасов.

Основное препятствие на пути внедрения новых технологий добычи угля - серьезное отставание отечественного машиностроения. В период перестройки и высоких экспортных цен на уголь отечественные угольные компании переориентировались на импорт зарубежного оборудования, экономическая эффективность которого обеспечивалась не столько техническими характеристиками, сколько выгодными условиями поставки, низкими процентными ставками по кредитам (3\% вместо 20\%), качественным сервисным обслуживанием. При этом в условиях больших доходов никто не думал о необходимости адаптации импортного оборудования и разработке специальных технологий, приспособленных к горно-геологическим условиям Кузбасса. Это также сдерживает переход угольной промышленности Кузбасса на интенсивный путь развития и толкает регион на путь ресурсного монопродуктового развития. Именно поэтому внедрение новых технологий добычи угля является важным моментом создания новых нисходящих ЦДС в Кузбассе. Использование в практике угольных компаний инновационных технологий добычи способно помочь отрасли пойти интенсивным путем освоения месторождений, тем самым снизив «технологические» потери угля, что положительно повлияет на экономику угледобывающих предприятий.

Модернизация технологий добычи открытым способом. В настоящее время практически 2/3 угля в России добывается открытым способом, и его доля в общем объёме добычи растет. Интенсивное развитие этого способа добычи требует постоянного решения сложных технологических проблем, выполнения научно-исследовательских работ, связанных с формированием транспортных систем, моделированием геодинамических процессов в горном массиве.
Особенностями открытых горных работ являются постоянное увеличение глубины угольного разреза, увеличение расстояний транспортирования и объемов перемещаемых горных пород. Они ведут к снижению производительности транспортно-погрузочного оборудования и росту затрат на перевозки, на которые приходится более $60 \%$ себестоимости добытого угля.

Анализ зарубежного опыта показывает, что глубина многих карьеров в настоящее время -400-500 м, а в перспективе может достигнуть 700-1000 м, при этом годовые объемы перемещаемой горной массы составляют около 30-50 млн м³. Эффективная отработка таких карьеров возможна только при рациональном сочетании различных видов транспорта (автомобильного, автомобильно-конвейерного и автомобильно-конвейерно-железнодорожного).

По мнению многих экспертов, единственным способом дальнейшего наращивания объемов производства и повышения его эффективности за счет сокращения затрат на транспортирование горной массы с нижних горизонтов глубоких карьеров является внедрение циклично-поточной технологии добычи угля с применением крутонаклонных конвейеров на угольных разрезах [16]. Впервые в мире эта технология была внедрена на разрезе «Богатырь» Экибастузского угольного бассейна, благодаря чему была достигнута самая высокая в отрасли среднемесячная производительность труда рабочего и самая низкая себестоимость добычи 1 т угля [17]. Внедрение элементов циклично-поточной технологии на разрезе «Павловский» (ООО «Приморскуголь», ОАО «СУЭК») позволило снизить себестоимость доставки угля на 25\%; снижены затраты на содержание автомобильных дорог из-за уменьшения их протяженности; удалось обойтись без приобретения дополнительных самосвалов «БелАЗ-7555» и отказаться от менее эффективной железнодорожной вскрыши за счет увеличения объемов и сокращения расстояния транспортирования автомобильной вскрыши [18].

Единственная пока в Кузбассе установка циклично-поточной технологии работает на Талдинском разрезе в составе ОАО УК «Кузбассразрезуголь» - крупнейшей компании в России, которая специализируется на добыче угля открытым способом. Установка обеспечивает транспортирование и укладку вскрышных пород в отвал. Ее применение позволило сократить расстояние 
транспортирования технологическими автосамосвалами до 2 км, а также формировать отвалы без применения бульдозеров. Установка работает круглосуточно, круглогодично с высокой производительностью - более $4000 \mathrm{~m}^{3}$ /ч. Корректировка проекта поля разреза «Таежный» с целью увеличения мощности до 8,5 млн т угля в год также предусматривает внедрение циклично-поточной технологии.

Модернизация технологий добычи подземным способом. Наиболее ценные, в том числе поставляемые на экспорт, марки угля в России добываются именно подземным способом (около 30\% всего объёма добычи угля). Значительная часть таких запасов сосредоточена в сложных горно-геологических условиях в крутых и крутонаклонных пластах мощностью от 1,5 до 20 м с углами залегания до 90 градусов.

В России мощные крутые и крутонаклонные пласты есть в Кузнецком угольном бассейне (Кузбасс, Кемеровская область) и на Апсатском каменноугольном месторождении в Читинской области на территории Каларского района Забайкальского края. Только в Кузбассе в таких пластах сосредоточено более 1 млрд т. Кроме того, они распространены в странах ближнего и дальнего зарубежья (месторождения Закавказья (Ткварчельское и Шаорское), Средней Азии (Шаргуньское), а также Польши, Китая, Болгарии, Индии, Турции). Залегающие в таких условиях угли уникальны по своему составу, в основном представлены особо ценными марками, служат главной сырьевой базой для металлургической и углехимической промышленности России.

Существующая традиционная технология с применением щитового способа добычи угля из крутых и крутонаклонных пластов малоэффективна из-за низкой полноты выемки угля из пласта и отличается повышенной опасностью взрыва метана в шахте в связи с применением буровзрывного способа разупрочнения угольного массива. Поэтому она практически не используется.

В настоящее время в мире отсутствуют безопасные технологии добычи и высокопроизводительные очистные комплексы для эффективной и безопасной подземной разработки мощных крутых и крутонаклонных угольных пластов. Существующие отечественные комплексы для слоевой выемки пологих пластов в данных горно-геологических условиях использоваться не могут в связи с низкой эффективностью. В результате крутые и крутонаклонные мощные пласты в России и в других угледобывающих странах подземным способом практически не разрабатываются.

Учёные Института угля Федерального исследовательского центра угля и углехимии СО РАН в качестве эффективного решения проблемы видят отработку таких пластов по технологии с управляемым выпуском, а также разработку средств механизации на основе применения безлюдных технологий (роботизированных систем), обеспечивающих полноту выемки угля и значительное повышение уровня безопасности.

Предварительные экономические расчеты, выполненные в соответствии с «Методическими рекомендациями по оценке эффективности инвестиционных проектов», подтвердили заявленные эффекты на примере опытно-промышленного участка на действующей шахте.

Предлагаемые новые технологии и роботизированные системы для их реализации могут успешно применяться для подземной разработки мощных угольных пластов, а также алмазосодержащих и рудных месторождений полезных ископаемых.

Заинтересованными потребителями технологических решений являются отечественные и зарубежные компании, планирующие добычу угля из мощных крутонаклонных пластов: ЗАО «Тувинская энергетическая промышленная корпорация», ООО «Распадская угольная компания», ОАО «Южный Кузбасс», ОАО «СУЭК», АО «Сакнахшири» (Грузия), АО «АрселорМиттал Темиртау» (Казахстан), Ангренское месторождение (Узбекистан), Куангниньский угольный бассейн (Вьетнам), Coal India Ltd. (Индия) и др.

При внедрении данной технологии можно говорить о «втором дыхании» для шахт Прокопьевско-Киселёвского угольного комплекса и других законсервированных шахт с сохранившейся технологической инфраструктурой.

Инновационное развитие угольной отрасли и формирование перспективных ЦДС невозможны без технологической модернизация смежных и обеспечивающих производств, к которым относятся, в первую очередь, машиностроение и железнодорожная инфраструктура. 
Важным моментом создания новых ЦДС является также развитие транспортной инфраструктуры и каналов дистрибуции угля. Наконец, интенсивное развитие угольной отрасли Кузбасса требует активного формирования региональных институтов развития, в том числе государственно-частного партнерства, способных обеспечить инвестиционный поток, необходимый для развития угольной отрасли в регионе.

\section{Выводы}

Подводя итог, можно утверждать, что динамичное развитие кузбасской экономики требует формирования эффективной инновационной системы, с созданием блоков развития. Для этого регион должен развиваться на основе новой индустриальной базы, которая предполагает тесное сотрудничество добывающих и перерабатывающих отраслей с широким кругом смежных и поддерживающих производств (машиностроительные, сервисные и инжиниринговые компании и транспортная инфраструктура), с участием государства и научно-образовательных организаций, которые могли бы помочь угольной отрасли стать движущей силой интенсивного и инновационного направления развития региона. Представляется, что именно взаимосвязь между ресурсными отраслями и другими секторами экономики будет способствовать решению этой проблемы.

Взаимодействие отраслей в рамках восходящих и нисходящих ЦДС способно разорвать порочный круг и создать новые условия для развития. Ресурсные отрасли, наконец, начнут генерировать спрос на инновации, отечественную машиностроительную продукцию, инжиниринговые и сервисные услуги, финансы, транспорт и маркетинг, стимулировать развитие внутреннего, в том числе регионального рынка.

Для «вживления» новых звеньев в существующие технологические цепочки, по мнению авторов, на первом этапе требуется:

- реализовывать точечные инвестиционные решения, ориентированные на «развязывание узлов» и ликвидацию имеющихся «разрывов» в технологической цепи комплексного освоения угольных месторождений;

- выявлять рентабельные технологические звенья ЦДС, продукция которых имеет потенциальный спрос на мировом рынке, или этот спрос целенаправленно формируется на внутреннем рынке (в том числе в регионе, муниципалитетах);

- выявлять взаимные интересы и объединять усилия бизне$\mathrm{ca}$, науки и органов власти в формировании «территориальных заказов» на высокотехнологичную продукцию машиностроения, обеспечивающую реализацию в промышленной сфере новых технологических звеньев ЦДС.

Рационально-оптимальный выбор совокупности технологических цепочек добавленной стоимости, по мнению авторов, позволит обеспечить устойчивое развитие экономики региона на принципах рационального недропользования.

\section{Литература}

1. BP Statistical Review of World Energy 2016. 2016 (London) [Эл. реcypc]. URL: http://www.bp.com/content/dam/bp/pdf/energy-economics/ statistical-review-2016/bp-statistical-review-of-world-energy-2016-fullreport.pdf. (дата обращения: 20.06.2017).

2. Прогноз развития энергетики мира и России 2016. / под ред. А. А. Макарова, Л. М. Григорьева, Т. А. Митровой.- М.: ИНЭИ РАН-АЦ при Правительстве РФ, 2016.- 200 с.

3. Тарзанов И.Г. Итоги работы угольной промышленности России за январь-март 2017 года // Уголь.- 2017.- № 7. -С. 32-36.

4. Официальный сайт Министерства энергетики Российской Федерации [Эл. ресурc]. URL: https://minenergo.gov.ru (дата обращения: 20.06.2017);

5. Фридман Ю.А., Речко Г.Н., Логинова Е. Ю. Современная кузбасская экономическая модель: вызовы и риски // Вестник Кузбасского государственного технического университета.- 2017.№ 2.- C. 170-181. [Эл. ресурc]. URL: https://vestnik.kuzstu.ru/index. php?page=articles\&id=3237 (дата обращения: 20.06.2017);

6. Global value chains in a changing world / Edited by Deborah K. Elms and Patrick Low // Fung Global Institute (FGl), Nanyang Technological University (NTU), and World Trade Organization (WTO), 2013. Printing by WTO Secretariat, Switzerland, 2013.- P.21 .[Эл. ресypc]. URL: https:// www.wto.org/english/res_e/booksp_e/aid4tradeglobalvalue13_e.pdf (дата обращения: 20.06.2017).

7. Кондратьев В.Б. Глобальные цепочки добавленной стоимости в современной экономике. [Эл. ресурс]. URL: http://www.perspektivy. info/rus/gos/globalnyje_cepochki_dobavlennoj_stoi mosti_v_sovremennoj ekonomike_2014-03-17.htm (дата обращения: 20.06.2017);

8. Портер М. Конкурентное преимущество. Как достичь высокого результата и обеспечить его устойчивость.- М: изд-во «Альпина», 2005.- 716 c.

9. Sturgeon T.J. How Do We Define Value Chains and Production Networks? // IDS Bulletin.- 2001.-Vol. 32.- № 3.- P. 9-18. DOI: 10.1111/ 
j.1759-5436.2001.mp32003002.x. (дата обращения: 20.06.2017); OECD (2015) Input-Output Tables. [Эл. pecypc]. URL: http://www.oecd.org/sti/ ind/input-outputtables.htm (дата обращения: 20.06.2017).

10. OECD (2013) Interconnected Economies: Benefiting from Global Value Chains. Paris: OECD. -54 p.

11. Последствия глобальных цепочек создания стоимости для торговли, инвестиций, развития и занятости. - Спб.: ОЭСР, ВТО, ЮНКТАД, 2013.- 34c. [Эл. pecypc]. URL: http://economy.gov.ru/minec/activity/ sections/foreigneconomicactivity/economic_organization/russiaj20j8/ doc20131205_7\# (дата обращения: 20.06.2017).

12. OECD (2015) Input-Output Tables. [Эл. ресурc]. URL: http://www. oecd.org/sti/ind/input-outputtables.htm (дата обращения: 20.06.2017). 13. ТЭК России - 2015.- М., 2016.- 64с.

14. Лазаренко С.Н., Кравцов П.В. Новый этап развития подземной газификации угля в России и в мире// Горный информационно-аналитический бюллетень (научно-технический журнал).- 2007.- № 5.C. 304-316.

15. Аналитический отчет «Анализ перспектив конверсии угля в нетопливные продукты в условиях российского рынка».- Кемерово: ООО «Сибирская издательская группа», 2016с.

16. Дауренбекова А. Н., Молдабеков Б. К. Перспективы применения циклично-поточной технологии на глубоких рудных карьерах. г. Алматы, Республика Казахстан//Вестник КазНТУ.- 2013.- № 4.- С. 3-8. 17. Ракишев Б. Р. Роль академика В.В. Ржевского в развитии горной промышленности и науки в республиках Центральной Азии. Тр. научного симпозиума «Неделя горняка-2010»: Отд. Вып. ГИАБ 1.- М., 2010.- № OB1. С. 31-42.

18. Инвестиционный проект «Строительство дробильно-погрузочного комплекса с применением ленточного конвейера для транспортировки угля с добычных забоев». п. Новошахтинский: Ру «Новошахтинское» ОАО «Приморскуголь», 2011. 